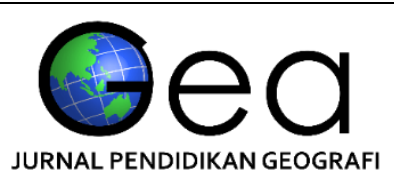

\title{
CONSTRAINTS IMPLEMENTATION OF GEOGRAPHY LEARNING PROCESS BASED ON CURRICULUM 2013 AT SENIOR HIGH SCHOOL (CASE STUDY IN BACKWARD REGIONS OF LEBAK REGENCY, BANTEN PROVINCE)
}

\author{
Rahmatia ${ }^{1}$, Ahmad Yani ${ }^{2}$, Nandi ${ }^{3}$ \\ ${ }^{1}$ Magister Program of Geography Education, Universitas Pendidikan Indonesia \\ 2,3 Department of Geography Education, Universitas Pendidikan Indonesia \\ 1nnrahmatia@student.upi.edu, ${ }^{2}$ ahmadyani@upi.edu ,3ㄹandi@upi.edu
}

\begin{abstract}
One part of the territory of the Republic of Indonesia that has been difficult to carry out the education process in accordance with the Standards of the Learning Process based on the 2013 curriculum, especially in backward regions of Lebak Regency, Banten. The condition of backward regions which still has obstacles to accessing and organizing education based on the 2013 Curriculum. Thus, the successful implementation of the 2013 Curriculum in backward regions would be a challenge to implement it appropriately and in accordance with established standards. This study aims to determine constraints implementation of geography learning process based on Curriculum 2013 at senior high school. This research uses qualitative approach with descriptive method. The principal participants in this study were Geography teachers at Senior High School who have implemented the Curriculum 2013 in backward region of Lebak Regency, Banten. Meanwhile, the participants of the base are learners and academic supervision. The research instruments are observation, interview, and document review.
\end{abstract}

Keywords: Obstacles, Curriculum 2013, Geography Learning.

\section{INTRODUCTION}

Curriculum 2013 requires preparation in various aspects, from manuals, standard operational procedures, training materials, student books, teacher manuals, regulations and so on (Kompasiana.com, 2013). The demand for preparedness from various aspects is not in line with backward regions condition which still has obstacles to access and organize education which is standard of Curriculum 2013. Thus, the successful implementation of Curriculum 2013 in backward region would be a challenge to implement it properly and in accordance.

Even in terms of implementation of the learning process in general, so far schools in the backward regions held education with all the limitations that exist. According Murniasih, the impediment of education is influenced by the availability of facilities and infrastructure, the availability of funds, and the ability of teachers to develop effective learning models. As a result, the learning process only takes place conventionally (Murniasih, Subagia \& Nyoman Sudria, 2013). In line with that described by Syukri, the problem is reflected in the teaching-learning activities that in the learning process and its assessment put more emphasis on the cognitive aspect, the attitude and skill aspects become disregarded. This happens because the teacher only 
understands theoretically about the preparation of an attitude and skills assessment instrument but has not been able to practice it in the preparation, implementation in the classroom, and how to analyze the results of its implementation in the classroom (Syukri, 2014).

The backward regions that became the object in this study, namely Lebak Regency, Banten. Selection of Lebak Regency, Banten as the object of research is based on two indicators of consideration. The first consideration, related problems in the area Lebak Regency both physically and socially. The second consideration is the accessibility between Lebak Regency with Jakarta City which became the center of Indonesian government is only about 100 kilometers. This is very ironic, because with a relatively close distance, but there are still areas that fall into the category of lagging. The third consideration, the Human Development Index (HDI) is low, such as the low average school age and school enrollment rates.

The consideration of the location chosen by the researcher is based on the data obtained by the researcher that Lebak Regency has literacy rate of $98.07 \%$, the average length of school only reaches 5.84 years or equal to grade 6 (grade VI) and is the lowest in Banten Province, School Participation Rate of 7-12 years old is 99.14 percent, 13-15 years of 92.71 percent and 16-18 years of 58.32 percent (Peraturan Badan Perencanaan Pembangunan Nasional, 2015).

The overall data that has been described previously, shows the low quality of human resources in Lebak Regency. And, affirming that the biggest challenge for Lebak Regency is the effort to improve the quality of human resources which has been one of the obstacles in the development process of Lebak Regency. Because, the better the education obtained, the hope that the community will more easily absorb information related to development, as a means to improve the standard of living and welfare of society

The low quality of human resources in Lebak Regency is closely related to the complex educational problems. First, most school quality has a low quality of education, reflected in school accreditation achievements and the average national exam score (Tim Puslitjak and Jarlit, 2014). Secondly, the low level of community education. Third, the condition and availability of educational facilities are very considerate because they have not met the appropriate and adequate standards, especially the high school education facilities (Peraturan Badan Perencanaan Pembangunan Nasional, 2015).

\section{RESEARCH METHOD}

Researchers choose to use a qualitative research approach to determine how to find, collect, process and analyze data research results. The type of method used in this research is descriptive. The main participants in this study, namely Geography teacher at senior high school, Banten who has implemented the Curriculum 2013 in backward regions of Lebak Regency, Banten. Meanwhile, the participants of the base are learners and academic supervision which in this case can be represented by the authorities, such as the principal, deputy head of the curriculum, or supervisor academic. To obtain the necessary data in this research, the data collection process that will be used researcher is semistruktur interview, participant observation, and document review.

\section{FINDINGS AND DISCUSSION}

Constraints to Standard Implementation

An important problem that is often faced by teachers in learning activities is to 
prepare the right RPP process planning tools in order to help students achieve competencies. This is due to the fact that in the curriculum or syllabus, RPP is only outlined in the form of reference material for teaching. It is the teacher's duty to describe the reference material for teaching so that it becomes a complete teaching material.

The teacher has some difficulties, including; First, the process of reviewing the syllabus in order to develop and determine indicators of material in the RPP. Therefore, the teacher strives to overcome these obstacles by trying to find relevant sources and discuss them with the MGMP Geography. Because, when viewed from the competency of students, students tend to need fulfillment of needs in mastering cognitive aspects first. Thus, teachers experience confusion as to how to develop these indicators to meet aspects of skills and attitudes.

Second, the teacher has difficulty developing RPP by accommodating thematic learning, cross-subject integration for attitudes and skills, this is because the teacher is still focused on the content of the subject because the level of student competence in geography is still quite low.

Third, the determination of learning resources. Because, schools lack the provision of Geography subject textbooks as a guide for students, as well as the economic abilities of weak students so that they are less able to buy LKS in Geography subjects. Fourth, assessment techniques because teachers are constrained in providing assessment instruments especially aspects of skills and attitudes.

Fifth, teachers experience difficulties in determining learning resources and developing assessment. Because, often after the RPP is prepared, the teacher needs to readjust the conditions or conditions on the ground, such as student competencies and availability of facilities and infrastructure.

To overcome these obstacles, teachers always try to understand in order to gain insight into the development of RPP, both through the internet, MGMP, and discuss with other teacher friends. Meanwhile, related to learning resources, the teacher encourages students to search for material through the internet or any source before the material is explained at the next meeting. In addition, the teacher facilitates the students' books, because the books they have are limited, so the students are divided into groups to record the material first.

\section{Constraints in the Implementation of Standards}

In the implementation, there is no denying that teachers experience many obstacles and limitations especially after the curriculum changes as an effort to improve the quality of education or equal opportunities to get education. Constraints in the teaching and learning process of Geography, including; students who have a low reading level and the student is difficult to follow and follow the direction of the teacher, so that sometimes time runs out due to the length of the briefing. Because, in addition to delivering lessons or material, teachers must also educate so that they realize that respecting time is very important and guiding students to work well together.

In addition, in the implementation of Geography learning in High School Kab. Lebak Banten, which is a $3 T$ category, is a lack of learning awareness among students that may be influenced by economic factors, the mindset of parents who do not consider the importance of education and the atmosphere of learning at home that is not supportive. In addition, the unavailability of textbooks both in the 2013 textbook and Geography Worksheet 
curriculum, inadequate facilities and infrastructure and constrained time.

Constraints experienced by Geography teachers are facilities and infrastructure that are not yet fully available, for example the 2013 Geography Curriculum book, teaching aids, projector media, labs, and others. In addition, there are many teachers who feel that too much administration must be prepared to meet the demands of K13. What's more, student learning motivation is still low, which is generally influenced by a low economic level.

Threats that may still be a scourge of harm, harm and hindrance to achieving success in achieving educational goals in the future, are among others: low student learning motivation, cost constraints that are still a very influential factor, distance from home to school far away, and transportation that is rare or even nonexistent.

These things, can have an impact on the dropout of education at the high school level prematurely. In fact, schools are struggling and are very striving to help with the cost constraints of parents, but sometimes parents and students think more about mentoring work than going to school.

In addition, the possibility of difficulties faced by teachers in the future, is in an integrated assessment of aspects of knowledge, skills and attitudes. Also, changes in the RPP format that confuse teachers. In addition, the development of 2013 curriculum content continues.

To overcome obstacles or obstacles that are or will occur, it is necessary to make efforts to improve the implementation of the learning process to further improve the success of achieving educational goals. Therefore in an effort to improve this teaching process the role of the teacher is very important because the teacher is the manager, facilitator, mentor of teaching and learning activities.
The efforts that teachers do to improve and overcome the obstacles faced. The teacher tries to overcome the constraints of the unavailability of textbooks by giving assignments that must be collected at the next meeting or collecting materials, so that students can read first before the material to be discussed is delivered. For example, students collect material or pictures determined by the teacher through the internet.

As well as, guide and instill motivation and interest by inviting students to observe and analyze images, as well as problems that occur in the environment with regard to life both in the past, present, and future by solving problems that are solved in their own way which is considered good but still logical and rational. In addition, of course the lessons in PBM must be fun and should be better in teaching strategies.

\section{Constraints in the Implementation of Standards in the Assessment Process}

In an effort to achieve educational goals, it is important to know whether the business carried out is appropriate or in line with the objectives. The constraints that teachers face in carrying out the assessment of student learning outcomes by using an approach, namely the teacher can not conduct an assessment in accordance with the RPP. Due to the time that is not yet right. In addition, to assess all the processes in the implementation of teaching and learning, the teacher feels rather complicated, also the teacher's burden becomes more and more. Therefore, in order to overcome these obstacles, the teacher strives to make the best use of time, simplify the assessor, and strive to make the assessment process in accordance with the design. 
Constraints in the Implementation of Supervision Process Standards

In relation to the quality of education, the problems faced in school supervision, both in carrying out assessments, coaching, and monitoring are relevant and important things to discuss. In order to meet customer satisfaction, in this case students, parents, and other interested parties. Overall, it has run quite well, but there are still a small number of problems faced, namely in the follow-up of the results of supervision that have not been implemented effectively. In addition, the results of recording and documentation from the results of monitoring and supervision have not been well organized.

Therefore, both administratively and physical evidence as documentation is more well organized to find out how the differences in the development of the implementation of each National Education Standard (SNP), especially Process Standards can be observed from year to year, so that they can be used as evaluation and action go on. As well, it is recommended that supervision which includes monitoring, supervision, reporting and follow-up, can be carried out periodically, scheduled and continuously. In addition, the education unit itself can be better in implementing and following the system or regulation of the supervisory program standards that have been established nationally so that the supervision system in this education unit can be in harmony, harmonious and clear.

\section{CONCLUSIONS}

Based on the results of research that has been carried out to find out the obstacles in meeting the achievement of quality standards of the Geography Learning Process based on the 2013 curriculum in the District High School Lebak, Banten can be concluded that:
1. Implementation of Standards The process of planning Geography learning is based on the 2013 Curriculum in the District High School. Lebak, Banten is constrained in the process of reviewing the syllabus in order to develop and determine indicators of material in the RPP.

2. Implementation of Standards The process of implementing Geography learning is based on the 2013 Curriculum in the District High School. Lebak, Banten is constrained in the provision of facilities and infrastructure, the unavailability of a 2013 Curriculum package book to support students for independent learning, the low motivation and interest of students in learning, the thoughts of parents who are not yet open to the importance of education, the learning process has not emphasized aspects of knowledge, skills and attitudes proportionally, the teacher is still placed as the main learning resource, not yet utilizing learning resources outside the classroom that utilize the environment.

3. Implementation of Standards The process of evaluating Geography learning is based on the 2013 Curriculum in the District High School. Lebak, Banten is constrained by the difficulty of teachers to assess the entire learning process and still focus on assessing aspects of knowledge.

4. Implementation of Standards The process of supervising Geography learning is based on the 2013 curriculum in the District High School. Lebak, Banten is constrained by the absence of archiving activities and follow-up supervision that can improve the quality of learning quality. 


\section{RECOMENDATIONS}

Based on the discussion of the results of the research and its conclusions, the following are some suggestions as policy options that can be used as an alternative effort to improve the quality standard of the Geography learning process based on the 2013 Curriculum in the District High School. Lebak, Banten.

1. In the implementation of the learning process it is expected to provide facilities that support geography learning such as electronic media, geography teaching aids, learning resources and others that will develop students' knowledge, especially in geography subjects.

2. The need for innovative learning for teachers because with the scientific approach to the 2013 curriculum the teacher must be able to innovate in learning and read the situation of students in the classroom

3. The need for teacher professionalism in the implementation of the 2013 curriculum, because teachers must be able to divide their time to administer education administration with the learning process that students will receive

4. Efforts to implement the 2013 curriculum must consider the equitable distribution of infrastructure because in reality it still happens besides increasing the ability of teachers in learning to be improved, especially in the knowledge, skills and allocation of learning time which is felt to be less efficient with very much material on geographic material. it is also necessary to rearrange effective and efficient geography learning materials in order to facilitate teachers in the implementation of learning with the 2013 curriculum that uses a scientific approach.

5. In order for the quality of the Geography learning process to increase, it is necessary to improve the quality and performance of teachers, improve facilities and infrastructure, make improvements in the field of monitoring and evaluation in the implementation of the learning process.

6. To further improve the success of the Process Standard, there is a need for cooperation for each school in Kab. Lebak, Banten in order to be able to carry out constructive educational activities to be followed by all teachers and principals in Kab. Lebak, Banten.

7. It is necessary to raise awareness on all elements of the school, both principals, teachers, staff, students, including parents and the community, that to improve the quality of the standard Geography learning process, it is a shared responsibility, so they can contribute and contribute significantly towards the achievement of educational goals carried out by schools.

8. The results of this study can be used as additional references relating to the process standards to improve the quality of education.

9. For other researchers, to be able to continue similar research related to the quality standards of the 2013 Curriculum process, so that it can be used as additional information and useful for research.

\section{REFERENCES}

L. Murniasih., I. W. Subagia \& I. B. Nyoman Sudria. (2013). Pengelolaan Pembelajaran IPA: Studi Kasus pada SMP di Daerah Terdepan, Terluar, dan Tertinggal. Universitas Pendidikan Ganesha. e-Journal: Administrasi Pendidikan: Volume 4 Tahun 2013, 2013, p. 3.

Syukri. (2014). Implementasi Pendidikan Karakter dalam Kurikulum 2013 untuk Meningkatkan Kualitas Pembelajaran di 
MA Quraniyah Batu Kuta Narmada Lombok Barat. Jurnal Transformasi P2M IAIN Mataram. Transformasi, Vol. 10, No. 1, Januari-Juni 2014, 2014, p. 127.

Peraturan Badan Perencanaan

Pembangunan Nasional. Nomor 2421/Dt.7.2/04/2015 Tahun 2015, tentang Daftar Daerah Tertinggal dan Perbatasan. Diakses dari http://www.bappenas.go.id pada 11 Desember 2016.

Tim Puslitjak dan Jarlit. (2014) Pencapaian Standar Pengelolaan Pendidikan Dasar di Kabupaten Lebak. Laporan Penelitian Pemerintah Kabupaten Lebak, 2014.

Peraturan Badan Perencanaan Pembangunan Nasional. Nomor 2421/Dt.7.2/04/2015 Tahun 2015, op. cit. 